\title{
Chlorinated volatile organic compounds found near the water surface of heavily polluted rivers
}

\author{
*D. F. Juang; C. H. Lee; S. C. Hsueh \\ Department of Health Business Administration, Meiho Institute of Technology, 24F, 230, Ming-Chuan Second Road, \\ Kaohsiung 806, Taiwan
}

Received 12 April 2009; revised 18 July 2009; accepted 20 August 2009; available online 1 September 2009

\begin{abstract}
The objectives of this study were to identify the chlorinated volatile organic compounds near the water surface of two heavily polluted rivers in the south of Taiwan and compare their concentration distributions. Air samples were collected seasonally at the upstream, midstream and downstream water surfaces of each river and the chlorinated volatile organic compounds were analyzed qualitatively and quantitatively by gas chromatography and electron capture detector. Totally, twelve kinds of chlorinated volatile organic compounds were found at the water surfaces of both rivers and many of them were reported to be carcinogenic or probably carcinogenic to human. The results showed that each chlorinated volatile organic compound had its own distribution pattern and no good correlation of chlorinated volatile organic compounds between both rivers was obtained. The chlorinated volatile organic compounds identified at the river water surface of Fong Shan Stream showed much higher concentration than those of Chuen-Tsen River. Several chlorinated volatile organic compounds, including chlorodibromomethane, hexachlorobutadiene, 1,1,2,2-tetrachloroethene and 1,2dibromo-3-chloropropane were found with much higher concentration (mean concentrations of $124.5 \mu \mathrm{g} / \mathrm{m}^{3}, 334.5 \mu \mathrm{g} /$ $\mathrm{m}^{3}, 92.2 \mu \mathrm{g} / \mathrm{m}^{3}, 268.4 \mu \mathrm{g} / \mathrm{m}^{3}$, respectively) at the water surface of Fong Shan Stream in some seasons (especially spring and summer, summer and winter, spring and winter, spring and summer, respectively) and they were reported to be possibly carcinogenic to human. Therefore, it may be concluded that the people living close to Fong Shan Stream possibly had higher health risks due to the release of volatile organic compounds from the heavily polluted river.
\end{abstract}

Keywords: Carcinogen; Chlorinated aliphatic compounds; Chlorobenzenoic compounds; Health risk assessment; River water

\section{INTRODUCTION}

Since most researchers investigated the volatile organic compounds in surface water, treated wastewater or ground water (Nikolaou et al., 2002; Watson et al., 2003; Rivett et al., 2005; Chapmana et al., 2007; Ellis and Rivett, 2007; Pejman et al., 2009), it is difficult to find research references studying volatile organic compounds (VOCs) evaporating out of river water surface. Pankow (1996) reported that in deep, slow-moving flows, MTBE (methyl-tert-butyl ether) volatilizes at rates similar to those for the BTEX compounds (benzene, toluene, ethyl benzene and xylene). In shallow, fast-moving flows, MTBE volatilizes more slowly than benzene, though in such flows both MTBE and benzene volatilize quickly enough that these differences may seldom have much practical significance. Yamamoto et al. (1997) investigated the levels and distribution of 55 VOCs

*Corresponding Author Email: x2060@email.meiho.edu.tw Tel.: +886 8779 9821; Fax: +886 87780673 on water samples from 30 sites within the urban rivers and estuaries of Osaka, Japan. They detected 40 VOCs and the levels of dichloromethane (DCM) were higher at all of the sampling sites. DCM, toluene, 1,2,3trichloropropane (PCP) and 1,4-dichlorobenzene were detected in many sites at levels sometimes above $100 \mu \mathrm{g} / \mathrm{L}$. 1,1,1-trichloroethane (MC), benzene, trichloroethene (TCE), 1,2-dichloropropane, tetrachloroethene (PERC), chlorobenzene, ethylbenzene, 1,3-xylene, 1,4-xylene, 1,2-dichlorobenzene (1,2-DCB) and 1,2,4-trimethylbenzene were found at a level of $10 \mu \mathrm{g} / \mathrm{L}$ or more.

Kostopoulou et al. (2000) investigated the most commonly encountered VOCs in the surface waters of northern Greese and they found chloroform, carbon tetrachloride, bromodichloromethane (BDCM), chlorodibromomethane (CDBM), TCE, PERC. Rathbun (2000) discussed the processes affecting the transport, behavior and fate of VOCs in streams and 
concluded that water velocity, flow depth, water temperature of the streams would be the major factors affecting the volatilization of VOCs. Since vinyl chloride (VC) has been reported to be carcinogenic to human, Yamamoto et al. (2001) also studied its contamination in shallow urban rivers in Osaka, Japan. They concluded that VC concentrations ranged from below detection limit to $55.60 \mu \mathrm{g} / \mathrm{L}$ with the mean of $3.35 \mu \mathrm{g} / \mathrm{L}$ and the standard deviation of $5.96 \mu \mathrm{g} / \mathrm{L}$. They also found that the concentrations of cis-1,2dichloroethene (c-DCE), PERC and TCE were significantly correlated to VC concentrations in the rivers, with the relative ratios of about $1: 2.7: 1.5$ : 0.31 (VC: c-DCE: PERC : TCE). The concentrations of the four VOCs decreased with distance down the river. Nikolaou et al. (2002) detected 15 kinds of VOCs in surface water and 31 types of VOCs in wastewater. However, they concluded that the concentrations of these observed VOCs did not exceed the guideline values of European Community. The concentrations of VOCs in the rivers were mostly in the range between ND (not detectable concentration) to $6.7 \mu \mathrm{g} / \mathrm{L}$. The concentrations of VOCs in the lakes were mostly in the range between ND to $2.0 \mu \mathrm{g} / \mathrm{L}$ and they were in the range between ND to $664 \mu \mathrm{g} / \mathrm{L}$ in wastewater. Watson et al. (2003) also investigated the sources of earthy/musty VOCs, including geosmin, 2methylisoborneol (MIB), 2,4,6-trichloroanisole (2,4,6TCA), 2-isopropyl-3-methoxypyrazine and 2-isobutyl3-methoxypyrazine, from a pulp and paper mill in Canada. They found very high concentration (between 1,600 and $128,000 \mathrm{ng} / \mathrm{L}$ ) of geosmin in the water samples taken from activated bioreactor. The concentrations of MIB in the sludge samples of bioreactor were between 25 and 24,000 ng/L. Rivett et al. (2005) reported that TCE, PERC, 1,1,1-TCA, TCM (trichloromethane) and c-DCE were the most frequently found chlorinated VOCs in the aquifer groundwater in Birmingham, UK. Recently, Ellis and Rivett (2007) assessed the impact of urban VOC contaminated groundwater on the water quality of River Tame in UK.

They concluded that overall surface water quality deterioration in River Tame was not very significant although Tame valley had a long industrial history and significant VOC aquifer contamination. However, they found aquifer groundwater contained significant chlorinated VOC contamination. Many kinds of chlorinated VOCs were found, including TCE, TCA,
PERC, DCE, 1,1-DCA (1,1-dichloroethane), TCM, etc. Their maximum concentrations were about in the range of 0.1 to $100 \mu \mathrm{g} / \mathrm{L}$. Liu et al. (2007) measured the levels of ambient VOCs in the Pearl River Delta Region, China and found that alkanes constituted the largest percentage ( $>40 \%$ ) in mixing ratios of the quantified VOCs at six sites and only one major industrial site that was dominated by aromatics (about 52 \%). Soltanali and Shams Hagani (2008) used a Monte Carlo simulation technique to estimate the VOCs stripping from biological treatment processes. They found that the model values agreed well with the experimental data for benzene, toluene, methylene chloride, TCE, and methyl isobutyl ketone.

\section{Description of the polluted rivers}

The volatile organic compounds possibly evaporating out of the water surface of two polluted rivers located in the south of Taiwan were studied from August 2003 to July 2005. One of the rivers, located in Kaohsiung County, was called Fong Shan Stream and it was called Chuen-Tsen River when it entered Kaohsiung City ( Fig. 1). The length of ChuenTsen River and Fong-Shan Stream was about 3 and $17 \mathrm{~km}$, respectively. Both rivers have received domestic and agricultural wastewater for many years. Many industries of different type, such as leather, steel, chemical, petrochemical, lumber, electrical, pulp and plastic industries, were located mostly along the upstream riversides of Fong-Shan Stream and might discharge the wastewater into the stream. Chuen-Tsen River also received some types of industrial wastewater primarily from electronic and mechanical manufacturers. A Sewer Department of Kaohsiung Municipal Government (ASDKMG) (2003) investigated the VOCs in the water of Chuen-Tsen River and concluded that the VOCs primarily found in the upstream river water were volatile aromatic compounds such as methyl benzene (toluene) (1.10$3.55 \mu \mathrm{g} / \mathrm{L}$ in average), ethylbenzene (2.92-16.10 $\mu \mathrm{g} / \mathrm{L}$ in average), m,p-xylene (4.50-13.60 $\mu \mathrm{g} / \mathrm{L}$ in average), o-xylene (2.48-9.60 $\mu \mathrm{g} / \mathrm{L}$ in average), etc. However, chlorinated VOCs such as 1,2-DCA (up to $42.7 \mu \mathrm{g} / \mathrm{L}$ ), chloroethylene $(9.60 \mu \mathrm{g} / \mathrm{L}$ in average), cis-1,2dichloroethylene, PERC, bromodichloro -methane, 1,1,2-trichloroethane (1,1,2-TCE), chloroform, chloroethane, methyl t-butyl ether, etc. were primarily found in the downstream river water.

Both rivers, especially Fong-Shan Stream, have 
contained thick sludge sediments and had black appearances. People could smell the odor at a location near the river and see the bubbles coming out of the river water, as well. Since the wastewater discharged by those above mentioned industries very likely contained some hazardous volatile organic compounds, it is possible that for a long term the VOCs evaporated out of the river water surface might affect the health of the residents living along the riverside (Sacks and Akard, 1994). When VOCs are oxidized in the presence of oxides of nitrogen, they lead to the formation of photochemical smog, harmful to humans, animals and vegetation (Lewis and Davies, 1998). Therefore, as far as the public health is concerned, it is important that the possible chlorinated VOCs evaporating from the river water should be identified first and their concentration distribution characteristics will also be discussed in this article for the future work of risk assessment and management.

In this study, the species and the concentration distribution of VOC evaporating out of two heavily polluted rivers were investigated and it is hoped that the results could be helpful in the future studies of health risk assessment on the residents living very close to the river. This study was conducted from August 2003 to July 2005 and air samples were collected at the water surface of two heavily polluted rivers, Chuen-Tsen River and Fong Shan Stream, located in the south of Taiwan.

\section{MATERIALS AND METHODS}

VOCs sampling plan

The sampling locations of VOCs in this study were shown in Fig. 1. In order to understand how much of VOCs possibly evaporating out of the river and compare the concentration variation of VOCs evaporating at different locations of rivers, VOC samples were taken at the upstream (A), midstream (B) and downstream (C) water surfaces of Fong-Shan Stream and at the upstream (E), midstream (F) and downstream (G) water surfaces of Chuen-Tsen River. Sampling was performed seasonally, from August 2003 to July 2005 and during the noon time. The selected locations and the sampling time had less interference of air pollutants from vehicles. Since both rivers have received various types of industrial wastewater, it is expected that a variety of VOCs could evaporate out of the river water surface. In this article, it is only discussed about the chlorinated VOCs, since many of them were reported to be carcinogenic or probably carcinogenic to human. The air samples were taken using Gilian air sampling pumps (model LFS-113DC) and the stainless sampling tubes filled with Carbosieve and Tenax-TA absorbents. Air sampling pumps were calibrated by a BUCK M-5 flow calibrator (flow in the range from $1-6000 \mathrm{~mL} / \mathrm{min}$ ) before and after use. Sampling tubes made by Supelco Company were also cleaned up using nitrogen gas for 2-5 h at the flow rate of $50 \mathrm{~mL} / \mathrm{min}$ before use. At the time of sampling, the air samples were pumped at a low flow rate of $100 \mathrm{~mL} /$ min directly into the sampling tubes without passing through the pump body. The sampling time required for each tube was normally about 2-3 h. All of the sampling tubes were stored in a refrigerator at a temperature lower than $4{ }^{\circ} \mathrm{C}$. After the completion of sampling, all tubes were brought back to the laboratory immediately.

The absorbed VOCs were purged and trapped into the carrier with highly pure nitrogen gas after thermal desorption (TD) by Tekmar aero trap desorber (Tekmar 6000 ), and the purged VOCs were then injected into Gas Chromatography for further analysis (USEPA, 1984; 1994; Taiwan EPA, 1998; Wang et al., 2002). A special floating cover placed at about $10 \mathrm{~cm}$ above the surface of river water was applied for the sampling of VOCs evaporating out of the river. Field blanks and system blanks were taken for each sampling and at least one duplicate was done for each sample, as well. While the VOCs samples were taken, the data regarding whether conditions, such as wind speed, wind direction, temperature and humidity, were also measured and collected simultaneously.

\section{Chlorinated VOCs analytical methods}

After the air samples were taken at all of the locations shown in Fig. 1, they were then analyzed qualitatively and quantitatively. The chlorinated hydrocarbons were analyzed by HP 5890 SERIES-a! gas chromatography and electron capture detector (GC/ECD) with the application of fused silica capillary column, $70 \mathrm{~m}$ (length) $\times 0.53 \mathrm{~mm}$ (inside diameter) $\times 3.0 \mu \mathrm{m}$ (film thickness) (USEPA, 1984; USEPA, 1994; Taiwan EPA, 1998; Nikolaou, 2002).

\section{Statistical analysis}

All statistical analyses of the data were completed by using SPSS software (Juang et al., 2009) and the significance level of 0.01 was used in the linear 


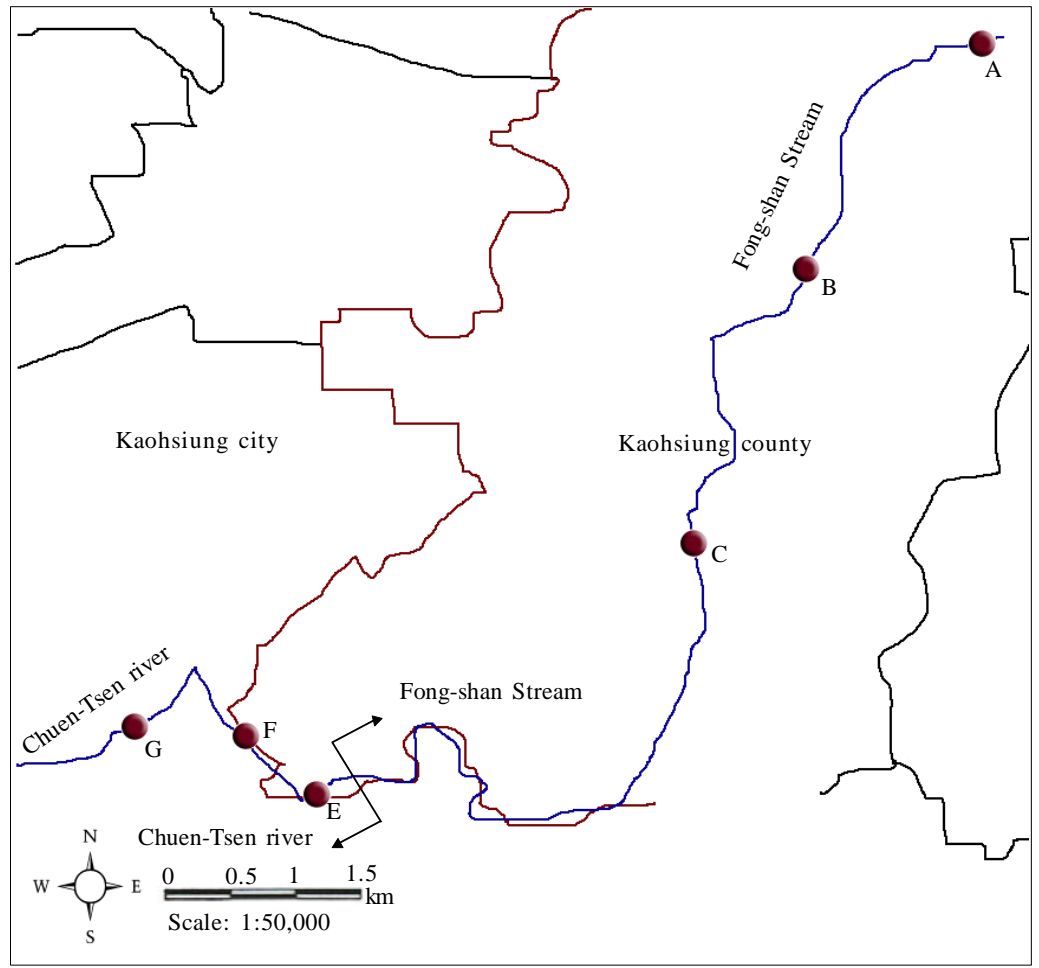

Fig. 1: Sampling locations of VOCs in this study

correlation tests among the chlorinated VOCs.

\section{RESULTS AND DISCUSSION}

Tables 1 and 2 showed the statistical data of VOCs found at the water surfaces of Chuen-Tsen River and Fong-Shan Stream, respectively. Totally, twelve kinds of chlorinated VOCs were identified from both rivers and many of them were reported to be carcinogenic or probably carcinogenic to human. The chlorinated VOCs found in this study were separated into two major types, including nine chlorinated aliphatic VOCs and three chlorobenzenoic VOCs. For chlorinated aliphatic VOCs, only chloromethane (CM) was not detected at the water surface of Fong Shan Stream. However, 1,3dichloropropane, 1,1,2- trichloroethane and tetrachloroethene were not identified at the water surface of Chuen-Tsen River. Basically, these chlorinated VOCs were usually found in the wastewater from the industries along both rivers, especially from chemical, petrochemical and plastic industries. In this study, air temperature and wind speed were measured during the sampling periods of every season and the results were shown in Table 3. Since no much difference of air temperature and wind speed was found among four seasons, the influence of both factors was neglected in this study.

Levels and distribution of chlorinated aliphatic VOCs

According to Fig. 2, levels of chlorinated aliphatic VOCs were much lower at the water surface of ChuenTsen River than Fong Shan Stream every season, except chloromethane. The discharge of wastes from the industries along the riversides of Fong Shan Stream probably contained much higher concentration of chlorinated aliphatic chemicals. Basically, the concentrations of all chlorinated aliphatic VOCs identified at the water surface of Chuen-Tsen River were much lower than those found in the river water by ASDKMG (2003). In Fong Shan Stream, only bromodichloro- methane 1,1,2-trichloroethane (1,1,2TCE) and hexachlorobutadiene (HCBD) appeared higher concentrations at the water surface of upstream than downstream. No such relationship was found on the other chlorinated aliphatic VOCs. 
Int. J. Environ. Sci. Tech., 6 (4), 545-556, Autumn 2009

Table 1: Statistical data of chlorinated VOCs found at the water surfaces of Chuen-Tsen River

\begin{tabular}{|c|c|c|c|}
\hline Chlorinated VOCs & Sample size & Concentration means & SD \\
\hline Chloromethane & 12 & 0.283 & 0.432 \\
\hline Chlorodibromomethane & 12 & 3.366 & 5.148 \\
\hline Bromodichloromethane & 12 & 0.563 & 1.293 \\
\hline 1,1,2-Trichloroethane & 12 & ND & - \\
\hline 1,2-Dibromo-3-Chloropropane (DBCP) & 12 & 0.703 & 0.950 \\
\hline Tetrachloroethene & 12 & ND & - \\
\hline 1,2-Dichlorobenzene (1,2-DCB) & 12 & 0.734 & 1.077 \\
\hline 1,2,3-Trichlorobenzene (1,2,3-TCB) & 12 & 0.143 & 0.231 \\
\hline 1,2,4-Trichlorobenzene (1,2,4-TCB) & 12 & 0.198 & 0.407 \\
\hline
\end{tabular}

*Note: ND means not detectable concentration and the concentration unit in this table is $\mu \mathrm{g} / \mathrm{m}^{3}$.

Table 2: Statistical data of chlorinated VOCs found at the water surfaces of Fong-Shan Stream

\begin{tabular}{lcrr}
\hline Chlorinated VOCs & Sample size & Concentration means & SD \\
\hline Chloromethane & 12 & ND $^{*}$ & ND \\
Chlorodibromomethane & 12 & 124.539 & 84.455 \\
Bromodichloromethane & 12 & 55.961 & 60.189 \\
1,3-Dichloropropane & 12 & 33.980 & 75.013 \\
1,1,2-Trichloroethane & 12 & 44.676 & 182.219 \\
1,2-Dibromo-3-Chloropropane (DBCP) & 12 & 268.428 & 91.078 \\
Tetrachloroethene & 12 & 72.283 & 66.537 \\
1,1,2,2-Tetrachloroethane & 12 & 92.234 & 233.496 \\
Hexachlorobutadiene & 12 & 334.472 & 99.095 \\
1,2-Dichlorobenzene (1,2-DCB) & 12 & 76.524 & 38.516 \\
1,2,3-Trichlorobenzene (1,2,3-TCB) & 12 & 32.562 & 64.498 \\
1,2,4-Trichlorobenzene (1,2,4-TCB) & 12 & 60.712 & \\
\hline
\end{tabular}

*Note: ND means not detectable concentration and the concentration unit in this table is $\mu \mathrm{g} / \mathrm{m}^{3}$.

Table 3: Air temperature and wind speed range during the sampling periods

\begin{tabular}{|c|c|c|c|c|}
\hline \multirow{3}{*}{ Season } & \multicolumn{4}{|c|}{ River } \\
\hline & \multicolumn{2}{|c|}{ Chuen-Tsen River } & \multicolumn{2}{|c|}{ Fong-Shan Stream } \\
\hline & Temp $\left({ }^{\circ} \mathrm{C}\right)$ & Wind speed (m/sec) & Temp $\left({ }^{\circ} \mathrm{C}\right)$ & Wind speed (m/sec) \\
\hline Fall & $32.2-32.3$ & $0.5-3.2$ & $29.8-31.3$ & $1.6-3.0$ \\
\hline Winter & $26.0-27.2$ & $2.2-3.0$ & $26.1-27.2$ & $2.2-3.0$ \\
\hline Spring & $27.2-27.6$ & 2.3-3.4 & $26.4-27.9$ & $1.7-3.5$ \\
\hline Summer & 30.4-32.5 & 4.1-5.6 & 31.3-33.0 & $1.2-1.9$ \\
\hline
\end{tabular}

In those identified VOCs from the water surface of Fong Shan Stream, chlorodibromomethane was detected at the levels from about 19 to $343 \mu \mathrm{g} / \mathrm{m}^{3}$ and bromodichloromethane was identified at the levels between ND (not detectable concentration) and 168 $\mu \mathrm{g} / \mathrm{m}^{3}$. Although CDBM was popularly found in surface waters, it was usually present in outside air at very low levels (less than $0.05 \mu \mathrm{g} / \mathrm{m}^{3}$ ) in USA. The levels of BDCM in air and in surface waters were usually quite low (always less than $0.8 \mu \mathrm{g} / \mathrm{m}^{3}$ ), with the averages of 4 and $200 \mu \mathrm{g} / \mathrm{m}^{3}$, respectively. Therefore, it might be said that the concentrations of both VOCs in the environment very close to Fong Shan
Stream could be higher than those values reported in USA. Basically, the levels of both VOCs, especially BDCM in summer, were usually higher at the upstream water surface than at the downstream water surface of Fong Shan Stream. It should be paid attention that both VOCs have been claimed to be carcinogenic to some experimental animals and possibly carcinogenic to human (IARC, 1987).

Levels of 1,3-dichloropropane (1,3-DCP) at the water surface of Fong Shan Stream were in the range from 5.5 to $267 \mu \mathrm{g} / \mathrm{m}^{3}$ and those of 1,1,2-TCE were between ND and $192 \mu \mathrm{g} / \mathrm{m}^{3}$. Since the United States Environmental Protection Agency (USEPA) suggested an inhalation 
D. F. Juang et al.
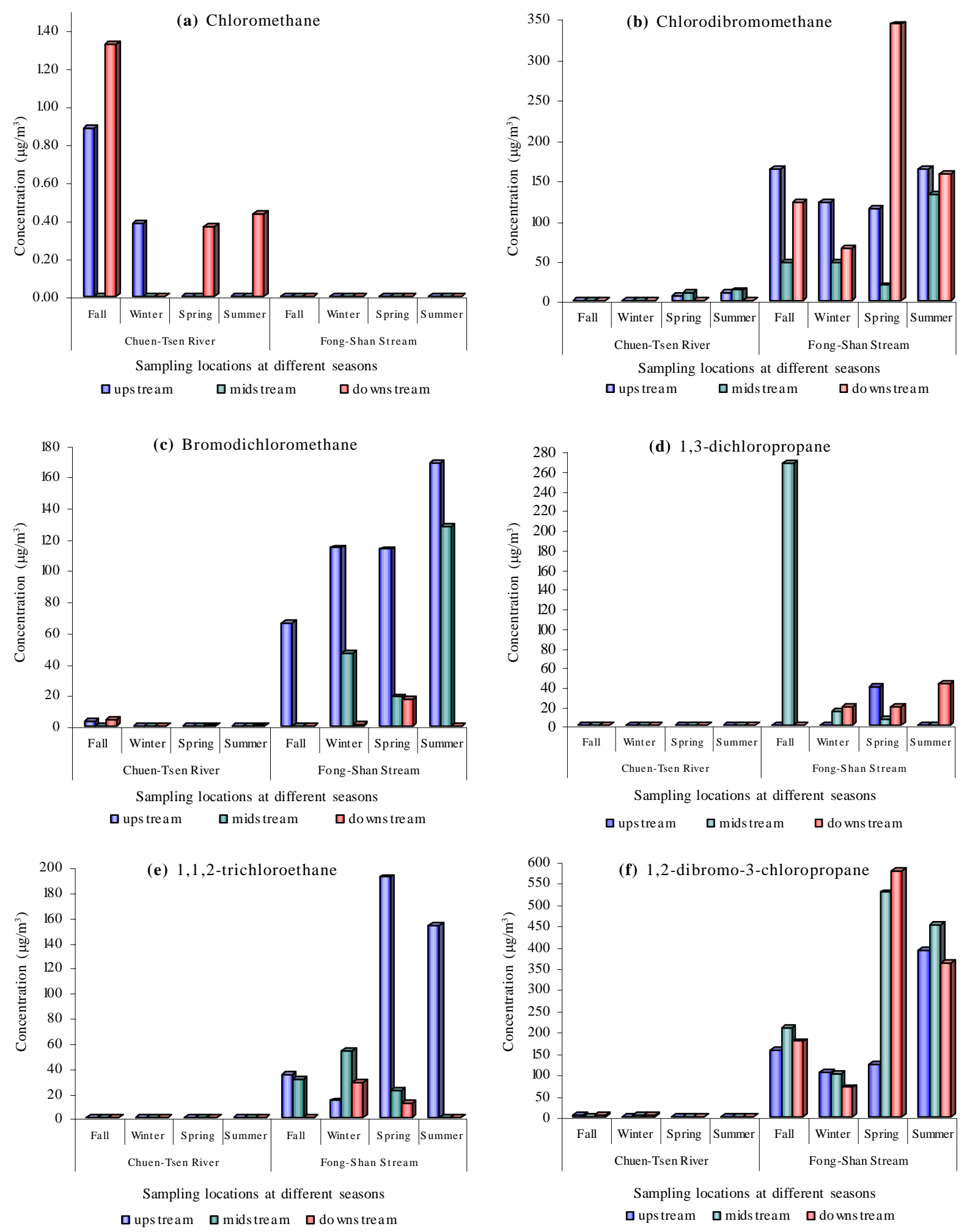

Fig. 2: Levels and distribution of chlorinated aliphatic VOCs 

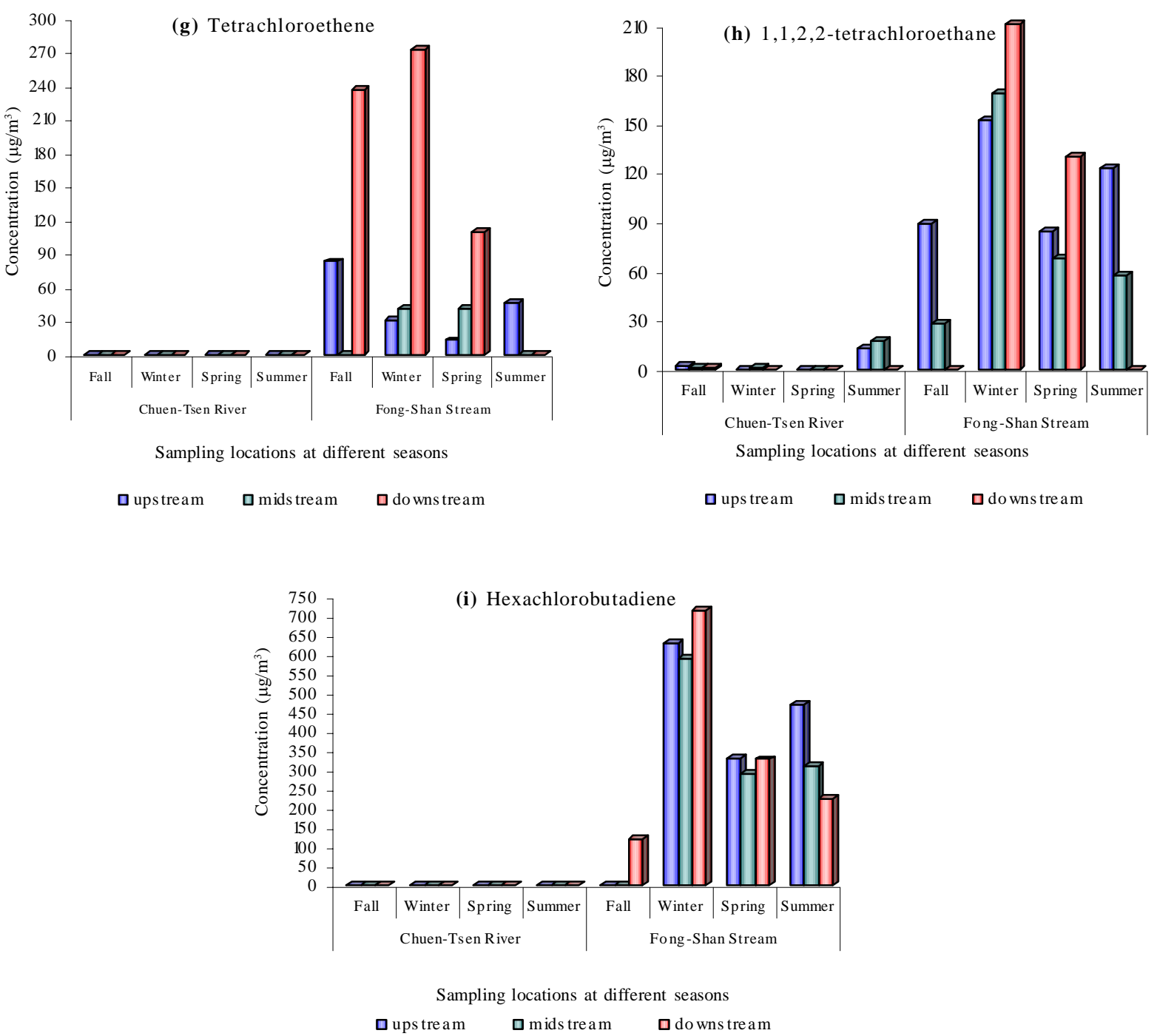

Fig. 2: Levels and distribution of chlorinated aliphatic VOCs (continued)

reference concentration value for $1,3-\mathrm{DCP}$ is $20 \mu \mathrm{g} / \mathrm{m}^{3}$, apparently the levels of this VOC at the water surface of Fong Shan Stream were sometimes higher than that value. According to the regulations of occupational safety and hygiene in Taiwan, the level limit of 1,1,2TCE in the air of working places is $5,500 \mu \mathrm{g} / \mathrm{m}^{3}$ which is much higher than the level found at the water surface of Fong Shan Stream.

At the water surface of Fong Shan Stream, levels of 1,2-dibromo-3-chloropropane (DBCP) were between 67 and $575 \mu \mathrm{g} / \mathrm{m}^{3}$ and those of tetrachloroethene were between ND and $271 \mu \mathrm{g} / \mathrm{m}^{3}$. For the people living in the areas close to a site with the air pollution of DBCP, it is very possible for them to inhale this VOC easily. Although the concentration of DBCP in the air is normally very low, OSHA (1989) has defined that the exposure level of this VOC should be less than $1 \mathrm{ppb}$ (about $9.55 \mu \mathrm{g} / \mathrm{m}^{3}$ ) $(8 \mathrm{~h} /$ day and over 40 weeks). The concentrations of this VOC found at the water surface of Fong Shan Stream in this study were obviously much higher than that limit. Although the concentrations of DBCP and PERC were up to 575 and $271 \mu \mathrm{g} / \mathrm{m}^{3}$, respectively, in this study, further studies should be required to confirm whether its concentration in river water will affect the growth of fish, shell, bacteria, etc. USEPA has collected and analyzed information on PERC 
levels in indoor and outdoor air and found the middle half $\left(25^{\text {th }}\right.$ to $75^{\text {th }}$ percentile $)$ of PERC levels in indoor and outdoor air samples is about 1 to $10 \mu \mathrm{g} / \mathrm{m}^{3}$ (NYSDH, 2003). Apparently, the levels of PERC found at the water surface of Fong Shan Stream were sometimes much higher than those values.

At the water surface of Fong Shan Stream, levels of 1,1,2,2-tetrachloroethane (1,1,2,2-TTCE) were in the range from ND to $210 \mu \mathrm{g} / \mathrm{m}^{3}$ and those of hexachlorobutadiene mostly ranged between 226 and $717 \mu \mathrm{g} / \mathrm{m}^{3}$. 1,1,2,2-TTCE was determined to be highly volatile. The major exposure ways of this VOC for human were indoor and outdoor inhalation. In the air of residential area in USA and Canada, the concentration of 1,1,2,2-TTCE was normally detected to be lower than $0.1 \mu \mathrm{g} / \mathrm{m}^{3}$ (IPCS, 1993; IPCS, 1994). Exposure of human to 1,1,2,2-TTCE might affect the functions of liver and kidney. 1,1,2,2-TTCE could enter into the river through the discharge of industrial wastewater and might then easily evaporate out of the river (Kaiser and Comba, 1983). Many researchers reported that the growth of fish, shell, bacteria, etc. in river could be affected while the concentration of $1,1,2,2-$ TTCE in river water was higher than $1 \mu \mathrm{g} / \mathrm{m}^{3}$
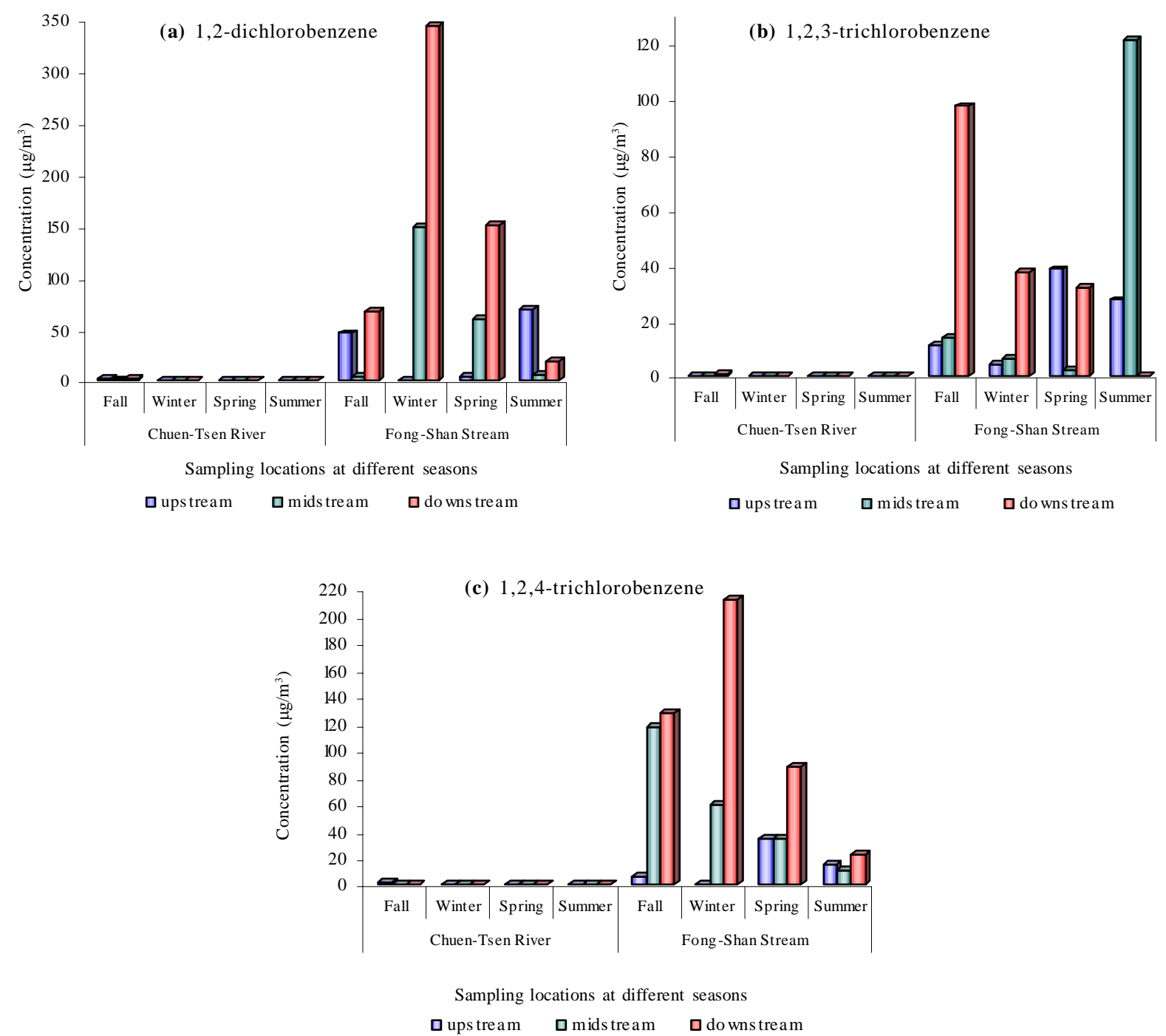

Fig. 3: Levels and distribution of chlorobenzenoic VOCs 
Int. J. Environ. Sci. Tech., 6 (4), 545-556, Autumn 2009

Table 4: Correlations between chlorinated VOCs found at the water surfaces of Chuen-Tsen River (sample size $=12$ )

\begin{tabular}{|c|c|c|c|c|c|c|c|c|c|c|}
\hline $\begin{array}{l}\text { Chlorinated } \\
\text { VOCs }\end{array}$ & Statistics & CM & CDBM & BDCM & DBCP & 1,1,2,2-TTCE & HCBD & 1,2-DCB & 1,2,3-ТCB & 1,2,4-ТCB \\
\hline \multirow[t]{2}{*}{$\overline{\mathrm{CM}}$} & Pearson correlation & 1.000 & -0.468 & 0.926 & 0.509 & -0.257 & -0.012 & 0.502 & 0.661 & 0.510 \\
\hline & Significant (two-tailed) & - & 0.125 & $0.000^{* *}$ & 0.091 & 0.421 & 0.972 & 0.097 & 0.019 & 0.091 \\
\hline \multirow[t]{2}{*}{ CDBM } & Pearson correlation & & 1.000 & -0.311 & -0.528 & 0.733 & -0.662 & -0.486 & -0.443 & -0.347 \\
\hline & Significant (two-tailed) & & - & 0.326 & 0.078 & $0.007^{* *}$ & 0.019 & 0.109 & 0.150 & 0.270 \\
\hline \multirow[t]{2}{*}{ BDCM } & Pearson correlation & & & 1.000 & 0.635 & -0.146 & -0.133 & 0.656 & 0.567 & 0.428 \\
\hline & Significant (two-tailed) & & & - & 0.026 & 0.650 & 0.680 & 0.020 & 0.055 & 0.165 \\
\hline \multirow[t]{2}{*}{ DBCP } & Pearson correlation & & & & 1.000 & -0.309 & 0.528 & 0.710 & 0.430 & 0.137 \\
\hline & Significant (two-tailed) & & & & 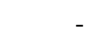 & 0.328 & 0.078 & $0.010^{* *}$ & 0.163 & 0.671 \\
\hline \multirow[t]{2}{*}{ 1,1,2,2-ТTCE } & Pearson correlation & & & & & 1.000 & -0.435 & -0.260 & -0.276 & -0.165 \\
\hline & Significant (two-tailed) & & & & & - & 0.158 & 0.415 & 0.384 & 0.609 \\
\hline \multirow[t]{2}{*}{ HCBD } & Pearson correlation & & & & & & 1.000 & 0.156 & 0.073 & 0.108 \\
\hline & Significant (two-tailed) & & & & & & 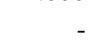 & 0.628 & 0.821 & 0.738 \\
\hline \multirow[t]{2}{*}{ 1,2-DCB } & Pearson correlation & & & & & & & 1.000 & 0.470 & 0.165 \\
\hline & Significant (two-tailed) & & & & & & & - & 0.123 & 0.608 \\
\hline \multirow[t]{2}{*}{ 1,2,3-ТСВ } & Pearson correlation & & & & & & & & 1.000 & -0.076 \\
\hline & Significant (two-tailed) & & & & & & & & - & 0.815 \\
\hline \multirow[t]{2}{*}{ 1,2,4-ТCВ } & Pearson correlation & & & & & & & & & 1.000 \\
\hline & Significant (two-tailed) & & & & & & & & & - \\
\hline
\end{tabular}

Note: ** indicates very significant correlation with a significance level of 0.01 (two-tailed)

Table 5: Correlations between chlorinated VOCs found at the water surfaces of Fong-Shan Stream (sample size $=12$ )

\begin{tabular}{|c|c|c|c|c|c|c|c|c|c|c|c|c|}
\hline $\begin{array}{l}\text { Chlorinated } \\
\text { VOCs }\end{array}$ & Statistics & CDBM & BDCM & 1,3-DCP & $\begin{array}{l}\text { 1,1,2- } \\
\text { TCE }\end{array}$ & DBCP & PERC & $\begin{array}{l}1,1,2,2- \\
\text { TTCE }\end{array}$ & HCBD & $\begin{array}{l}1,2- \\
\text { DCB }\end{array}$ & $\begin{array}{l}1,2,3- \\
\text { TCB }\end{array}$ & $\begin{array}{l}1,2,4- \\
\text { TCB }\end{array}$ \\
\hline \multirow[t]{2}{*}{$\overline{\mathrm{CDBM}}$} & Pearson correlation & 1.000 & 0.118 & -0.262 & -0.046 & 0.456 & 0.051 & 0.013 & -0.117 & -0.010 & 0.128 & -0.162 \\
\hline & Significant (two-tailed) & - & 0.714 & 0.410 & 0.888 & 0.137 & 0.875 & 0.968 & 0.718 & 0.976 & 0.692 & 0.614 \\
\hline \multirow[t]{2}{*}{ BDCM } & Pearson correlation & & 1.000 & -0.346 & 0.587 & 0.018 & -0.427 & 0.227 & 0.272 & -0.375 & 0.182 & -0.645 \\
\hline & Significant (two-tailed) & & - & 0.270 & 0.045 & 0.955 & 0.166 & 0.477 & 0.392 & 0.230 & 0.572 & 0.023 \\
\hline \multirow[t]{2}{*}{ 1,3-DCP } & Pearson correlation & & & 1.000 & -0.017 & -0.118 & -0.279 & -0.320 & -0.433 & -0.211 & -0.206 & 0.296 \\
\hline & Significant (two-tailed) & & & - & 0.959 & 0.715 & 0.381 & 0.311 & 0.159 & 0.510 & 0.520 & 0.351 \\
\hline \multirow[t]{2}{*}{ 1,1,2-TCE } & Pearson correlation & & & & 1.000 & -0.192 & -0.229 & 0.197 & 0.162 & -0.110 & -0.124 & -0.206 \\
\hline & Significant (two-tailed) & & & & - & 0.550 & 0.474 & 0.539 & 0.614 & 0.733 & 0.701 & 0.521 \\
\hline \multirow[t]{2}{*}{ DBCP } & Pearson correlation & & & & & 1.000 & -0.280 & -0.288 & -0.218 & -0.174 & 0.121 & -0.284 \\
\hline & Significant (two-tailed) & & & & & - & 0.378 & 0.363 & 0.496 & 0.588 & 0.707 & 0.371 \\
\hline \multirow[t]{2}{*}{ PERC } & Pearson correlation & & & & & & 1.000 & 0.288 & 0.211 & 0.750 & 0.293 & 0.776 \\
\hline & Significant (two-tailed) & & & & & & - & 0.364 & 0.511 & $0.005^{* *}$ & 0.356 & $0.003^{* *}$ \\
\hline \multirow[t]{2}{*}{ 1,1,2,2-TTCE } & Pearson correlation & & & & & & & 1.000 & 0.821 & 0.681 & -0.265 & 0.217 \\
\hline & Significant (two-tailed) & & & & & & & & $0.001^{* *}$ & 0.015 & 0.406 & 0.499 \\
\hline \multirow[t]{2}{*}{ HCBD } & Pearson correlation & & & & & & & & 1.000 & 0.557 & -0.120 & 0.151 \\
\hline & Significant (two-tailed) & & & & & & & & - & 0.060 & 0.711 & 0.639 \\
\hline \multirow[t]{2}{*}{ 1,2-DCВ } & Pearson correlation & & & & & & & & & 1.000 & -0.033 & 0.746 \\
\hline & Significant (two-tailed) & & & & & & & & & - & 0.919 & $0.005^{* *}$ \\
\hline \multirow[t]{2}{*}{ 1,2,3-ТСВ } & Pearson correlation & & & & & & & & & & 1.000 & 0.170 \\
\hline & Significant (two-tailed) & & & & & & & & & & - & 0.596 \\
\hline \multirow[t]{2}{*}{ 1,2,4-ТСВ } & Pearson correlation & & & & & & & & & & & 1.000 \\
\hline & Significant (two-tailed) & & & & & & & & & & & - \\
\hline
\end{tabular}


(Nestmann et al., 1980; Nestmann and Lee, 1983; Smith et al., 1991; Nichols et al., 1993). Although the concentration of 1,1,2,2-TTCE was up to $210 \mu \mathrm{g} / \mathrm{m}^{3}$ in this study, further studies should be required to confirm whether its concentration in river water will affect the growth of fish, shell, bacteria, etc. in Fong Shan Stream. However, according to the regulations of occupational safety and hygiene in Taiwan, the level limit of 1,1,2,2TTCE in the air of working places is $6,900 \mu \mathrm{g} / \mathrm{m}^{3}$ which is much higher than the level found at the water surface of Fong Shan Stream. HCBD is an intermediate in the manufacture of rubber compounds and lubricants. It is used as a fluid for gyroscopes, a heat transfer liquid, or a hydraulic fluid. HCBD has been considered to be a possible human carcinogen and according to the regulations of occupational safety and hygiene, its level limit in the air of working places in Taiwan is $210 \mu \mathrm{g} / \mathrm{m}^{3}$. It still needs to be noted that the concentrations of HCBD in this study were higher than this limit and might affect the health of people living in the areas close to the river, although the air samples were collected at the water surface of Fong Shan Stream.

\section{Levels and distribution of chlorobenzenoic VOCs}

The levels and distribution of chlorobenzenoic VOCs were illustrated in Fig. 3. The identified chlorobenzenoic VOCs included 1,2-dichlorobenzene (1,2-DCB), 1,2,3trichlorobenzene (1,2,3-TCB) and 1,2,4trichlorobenzene (1,2,4-TCB). The levels were ranged from ND to $344 \mu \mathrm{g} / \mathrm{m}^{3}$, from ND to $121 \mu \mathrm{g} / \mathrm{m}^{3}$ and from ND to $213 \mu \mathrm{g} / \mathrm{m}^{3}$ for 1,2-DCB, 1,2,3-TCB and 1,2,4-TCB, respectively. However, these identified chlorobenzenoic VOCs were different from those found by ASDKMG (2003). The average concentration of chlorobenzenoic VOCs at the river water surface was much higher for Fong Shan Stream than Chuen-Tsen River. Also, the concentrations of identified chlorobenzenoic VOCs appeared to be higher at the river water surface downstream than upstream of Fong Shan Stream.

This means that some wastewater containing these chlorobenzenoic chemicals was discharged along the river. Since Chuen-Tsen River is actually the downstream section of Fong Shan Stream, therefore the result abovementioned was coincident with the conclusion made by ASDKMG (2003) that volatile aromatic compounds were primarily found in the upstream river water of Chuen-Tsen River.
Statistical analysis

Tables 4 and 5 showed the linear correlations of the VOCs identified at the water surface of ChuenTsen River and Fong Shan Stream, respectively. Apparently, in Chuen-Tsen River, a very significant correlation (significance level $=0.01$ ) existed between CM and BDCM $(\mathrm{P}<0.01, \mathrm{R}=0.926)$, between CDBM and 1,1,2,2-TTCE $(\mathrm{P}<0.01, \mathrm{R}=0.733)$ and between DBCP and 1,2-DCB $(\mathrm{P}<0.01, \mathrm{R}=0.710)$.

In Fong Shan Stream, a very significant correlation (significance level $=0.01$ ) existed between PERC and 1,2-DCB ( $\mathrm{P}<0.01, \mathrm{R}=0.750)$, between PERC and 1,2,4-TCB $(\mathrm{P}<0.01, \mathrm{R}=0.776)$, between 1,1,2,2-TTCE and $\operatorname{HCBD}(\mathrm{P}<0.01, \mathrm{R}=0.821)$ and between $1,2-\mathrm{DCB}$ and $1,2,4-\mathrm{TCB}(\mathrm{P}<0.01, \mathrm{R}=0.746)$. It is apparent that the concentrations of 1,2-DCB, PERC and 1,2,4-TCB were very significantly correlated to each other, with the relative ratio of 1.26:1.19:1 (1,2-DCB:PERC:1,2,4TCB) according to the data in Table 2.

\section{CONCLUSION}

According to the results of this study, it seemed that individual chlorinated VOC has its own concentration distribution pattern and no good correlation of chlorinated VOCs between Chuen-Tsen River and Fong Shan Stream was obtained in this study. Basically, the concentrations of chlorinated VOCs at the river water surface of Fong Shan Stream were much higher than those of Chuen-Tsen River. Except CM, the levels of all other chlorinated VOCs were very low at the water surface of Chuen-Tsen River. Many chlorinated VOCs, such as CDBM, HCBD, PERC, 1,1,2,2-TTCE and DBCP, identified at the water surface of Fong Shan Stream showed much higher concentration in some season, and they were reported to be possibly carcinogenic to human. Therefore, the people living close to Fong Shan Stream possibly had higher health risks due to the release of VOCs from the heavily polluted river. However, further studies of health risk assessment regarding the effects of those VOCs on the health of those residents will be necessary. After statistical analysis, the Spearman's correlation coefficient between seasons and VOCs identified at the water surfaces of both rivers was only 0.017 . Therefore, the concentration distribution of each VOC at different seasons also presented a different pattern, especially in Fong Shan Stream. This is possible that the levels of VOCs discharged by industries might be different every season. 


\section{ACKNOWLEDGMENTS}

The authors would like to express their gratitude and appreciation to the National Science Council (NSC) of Taiwan for the financial support of this research.

\section{REFERENCES}

ASDKMG, (2003). Report of Cheun-Tsen River Environmental Monitoring Project (in Chinese), A Sewer Department of Kaohsiung Municipal Government, Kaohsiung Municipal Government, Kaohsiung City, Taiwan.

Chapmana, S. W.; Parkera, B. L.; Cherrya, J. A.; Aravenaa, R.; Hunkelerb, D., (2007). Groundwater-surface water interaction and its role on TCE groundwater plume attenuation. J. Contam. Hydrol., 91 (3-4), 203-232 (30 pages).

Ellis, P. A.; Rivett, M. O., (2007). Assessing the impact of VOC-contaminated groundwater on surface water at the city scale. J. Contam. Hydrol., 91 (1-2), 107-127 (21 pages).

IARC, (1987). Overall evaluations of carcinogenicity: An updating of IARC monographs 1-42, International Agency for Research on Cancer, Supplement 7, 195-196 (2 pages).

IPCS, (1993). International Chemical Safety Card - 1,1,2,2Tetrachloroethane. International Programme on Chemical Safety, No. 0332, World Health Organization (WHO), Geneva.

IPCS, (1994). Assessing human health risks of chemicals: Derivation of guidance values for health-based exposure limits. International Programme on Chemical Safety, Environmental Health Criteria 170, World Health Organization (WHO), Geneva.

Juang, D. F.; Yuan, C. S.; Hsueh, S. C.; Chiou, L. J., (2009). Distribution of volatile organic compounds around a polluted river. Int. J. Environ. Sci. Tech., 6 (1), 91-104 (14 pages).

Kaiser, K. L. E.; Comba, M. E., (1983). Volatile contaminants in the Welland River watershed. J. Great Lakes Res., 9 (2), 274-280 (7 pages).

Kostopoulou, M. N.; Golfinopoulos, S. K.; Nikolaou, A. D.; Xilourgidis, N. K.; Lekkas, T. D., (2000). Volatile organic compounds in the surface waters of Northern Greece. Chemosphere, 40 (5), 527-532 (6 pages).

Lewis, A.; Davies, J., (1998). Blue-sky chromatography: GC in flight. LC-GC Int., 11, 428-433 (6 pages).

Liu, Y.; Shao, M.; Lu, S. H.; Chang, C. C.; Wang, J. L.; Chen, G., (2007). Volatile organic compound (VOC) measurements in the Pearl River Delta (PRD) region, China. Atmos. Chem. Phys. Discuss., 8 (8), 1531-1545 (15 pages).

Nestmann, E. R.; Lee, E. G. H.; Matula, T. I.; Douglas, G. R.; Mueller, J. C., (1980). Mutagenicity of constituents identified in pulp and paper mill effluents using the Salmonella mammalian-microsome assay. Mutat Res., 79, 203-212 (10 pages).

Nestmann, E. R.; Lee, E. G.-H., (1983). Mutagenicity of constituents of pulp and paper mill effluent in growing cells of Saccharomyces cerevisiae. Mutat Res., 119, 273-280 (8 pages).
Nichols, J. W.; McKim, J. M.; Lien, G. J.; Hoffman, A. D.; Bertelsen, S. L.; Gallinat, C. A., (1993). Physiologicallybased toxicokinetic modelling of three waterborne chloroethanes in channel catfish, Ictalurus punctatus. Aquat. Toxicol., 27 (1), 83-112 (30 pages).

Nikolaou, A. D.; Golfinopoulos, S. K.; Kostopoulou, M. N.; Kolokythas, G. A.; Lekkas, T. D., (2002). Determination of volatile organic compounds in surface waters and treated wastewater in Greece. Water Res., 36 (11), 2883-2890 (8 pages).

NYSDH, (2003). Tetrachloroethene in indoor and outdoor air, Fact Sheet, 1-6, New York State Department of Health, USA.

OSHA, (1989). Air contaminants. Occupational Safety \& Health Administration, US Department of Labor. Final Rule, Federal Register, 54, 2933.

Pankow, J. F.; Rathbun, R. E.; Zogorski, J. S., (1996). Calculated volatilization rates of fuel oxygenate compounds and other gasoline-related compounds from rivers and streams. Chemosphere, 33 (5), 921-937 (17 pages).

Pejman, A. H.; Nabi Bidhendi, G. R.; Karbassi, A. R.; Mehrdadi, N.; Esmaeili Bidhendi, M., (2009). Evaluation of spatial and seasonal variations in surface water quality using multivariate statistical techniques. Int. J. Environ. Sci. Tech., 6 (3), 467-476 (10 pages).

Rathbun, R. E., (2000). Transport, behavior, and fate of volatile organic compounds in streams. Crit. Rev. Env. Sci. Tech., 30 (2), 129-295 (167 pages).

Rivett, M. O.; Shepherd, K. A.; Keeys, L.; Brennan, A. E., (2005). Chlorinated solvents in the Birmingham aquifer, UK: 1986-2001. Q. J. Eng. Geol. Hydroge., 38 (4), 337350 (14 pages).

Sacks, R.; Akard, M., (1994). High-speed GC analysis of VOCs: Tunable selectivity and column selection. Environ. Sci. Tech., 28 (9), 428A-433A (6 pages).

Smith, A. D.; Bharath, A.; Mallard, C.; Orr, D.; Smith, K.; Sutton, J. A.; Vukmanich, J.; McCarty, L. S.; Ozburn, G. W., (1991). The acute and chronic toxicity of ten chlorinated organic compounds to the American flagfish (Jordanella floridae). Arch. Environ. Con. Tox., 20 (1), 94-102 (9 pages).

Soltanali, S.; Shams Hagani, Z., (2008). Modeling of air stripping from volatile organic compounds in biological treatment processes. Int. J. Environ. Sci. Tech., 5 (3), 353360 (8 pages).

Taiwan EPA, (1998). Analytical methods for environment analytical methods for air (in Chinese). Taiwan EPA, Taipei, Taiwan.

USEPA, (1984). Compendium of methods for the determination of toxic organic compounds in ambient air, TO-1 EPA-600/ 4-84/041.

USEPA, (1994). Determination of total gaseous organic concentration using a flame ionization analyzer, 40 CFR Method 25A, 7-1-94.

Wang, X.; Sheng, G.; Fu, J.; Chan, C.; Lee, S. C.; Chan, L. Y.; Wang, Z., (2002). Urban roadside aromatic hydrocarbons in three cities of the Pearl River Delta, People's Republic of China. Atmos. Environ., 36 (33), 5141-5148 (8 pages).

Watson, S. B.; Ridal, J.; Zaitlin, B.; Lo, A., (2003). Odours from pulp mill effluent treatment ponds: The origin of significant levels of geosmin and 2-methylisoborneol (MIB). Chemosphere, 51 (8), 765-773 (9 pages). 
Chlorinated volatile organic compounds found near the river water surface

Yamamoto, K.; Fukushima, M.; Kakutani, N.; Kuroda, K., (1997). Volatile organic compounds in urban rivers and their estuaries in Osaka, Japan. Environ. Pollut., 95 (1), 135-143 (9 pages).
Yamamoto, K.; Fukushima, M.; Kakutani, N.; Tsuruho, K., (2001). Contamination of vinyl chloride in shallow urban rivers in Osaka, Japan. Water Res., 35 (2), 561-566 (6 pages).

\section{AUTHOR (S) BIOSKETCHES}

Juang, D. F., Ph.D., Associate professor, Department of Health Business Administration, Meiho Institute of Technology, 24F, 230, MingChuan Second Road, Kaohsiung 806, Taiwan. Email: x2060@email.meiho.edu.tw

Lee, C. H., Ph.D., Assistant professor, Department of Health Business Administration, Meiho Institute of Technology, Taiwan. Email: x2167@meiho.edu.tw

Hsueh, S. C., M.Sc., Lecturer, Department of Health Business Administration, Meiho Institute of Technology, Taiwan. Email: x3113@mail.meiho.edu.tw

How to cite this article: (Harvard style)

Juang, D. F.; Lee, C. H., Hsueh, S. C., (2009). Chlorinated volatile organic compounds found near the water surface of heavily polluted rivers. Int. J. Environ. Sci. Tech., 6 (4), 545-556. 